\title{
La primera etapa de El Jueves: un análisis de los primeros 26 números del semanario.
}

\author{
Gerardo Vilches
}

Gerardo Vilches Fuentes (Madrid, 1980) es licenciado en Historia por la UCM y máster en Métodos y técnicas de investigación historiográfica, geográfica y artística en el itinerario de Historia Contemporánea por la UNED. Trabaja actualmente en su tesis doctoral sobre las revistas satíricas de la transición. Ha participado como ponente en el iI Congreso internacional Grandes Narradores del Siglo xxi: "Alan Moore y sus alrededores", del departamento de Lengua Española y Teoría de la Literatura de la UCM (2011) y como comunicante en el i Congreso Internacional de Historia de la época socialista. España: 1982-1996 de la UNED (2011). En 2013 publica un ensayo dentro de la antología Watchmen. Radiografías de una explosión (Modernito Books) y varios textos en Panorama: la novela gráfica española hoy (Astiberri). Codirige CuCo, Cuadernos de cómic. 


\title{
Resumen
}

El Jueves fue la última de las grandes revistas satíricas que aparecieron durante el boom de las mismas en la transición española. Este artículo analiza y recorre la primera etapa de la misma, hasta su $26 .^{\circ}$ número, momento en el que la cabecera es comprada por el Grupo Zeta. En este análisis se prestará especial atención a la evolución de la ideología de la revista y su crítica a los procesos políticos que estaban teniendo lugar en 1977.

\begin{abstract}
El Jueves was the last of the great satirical magazines which appeared during the Spanish Transition. This paper analyzes and covers its first stage, until its number $26^{\text {th }}$, when the magazine was bought by Grupo Zeta. A special attention will be paid to the evolution of magazine's ideology and its critics to the political proccess which were taking place in 1977.
\end{abstract}




\section{Introducción}

El primer número de El Jueves apareció el 27 de mayo de 1977. Su caso es significativo porque es la única cabecera humorística surgida durante la transición que ha perdurado hasta la actualidad, a pesar de que fue la última de las grandes revistas que apareció; aunque puede que tal vez esa es precisamente la clave para entender su éxito. Este artículo analizará los primeros 26 números de El Jueves, a los que puede considerarse como primera etapa de la revista por ser los que se publican desde Editorial Formentera y con independencia de un gran grupo editorial. Como veremos, son números de experimentación, de ensayo y error, de secciones que vienen y van, de búsqueda, en definitiva, de una voz propia e individualizada dentro del panorama nacional.

\section{La edad de oro de la prensa satírica española.}

La transición española de la dictadura franquista a la democracia, entendida como el periodo que abarca desde el 20 de noviembre de 1975 — con la muerte de Francisco Franco - hasta la victoria socialista en las elecciones de 1982, es considerada como la edad de oro de la prensa semanal satírica. Pasada la década de los setenta, no obstante, ya son muy pocas las revistas que sobreviven en los quioscos, pero en los primeros años de apertura política es cierto que coincidieron un buen número de ellas, entre otras cosas porque se dio cierto relajamiento de la legislación, a pesar de que las publicaciones seguían bajo el ojo vigilante de la ley de prensa 14/1966, que vino a sustitutir a la desfasada legislación anterior, que databa nada menos que de 1938: la Ley de prensa aprobada por Serrano Suñer. Ahora la conocida popularmente como "Ley Fraga" introducía como principal novedad la eliminación de la censura previa, excepto en estados de guerra y excepción (artículo 3), al tiempo que garantizaba para la prensa la libertad de expresión, pero limitada por una serie de cuestiones detalladas en el artículo 2, que fue el motivo de prácticamente todas las sanciones impuestas a la prensa satírica:

La libertad de expresión y el derecho a la difusión de informaciones, reconocidas en el artículo primero, no tendrán más limitaciones que las impuestas por las leyes. Son limitaciones: el respeto a la verdad y a la moral; el acatamiento a la Ley de Principios del Movimiento Nacional y demás Leyes Fundamentales; las exigencias de la defensa Nacional, de la seguridad del Estado y del mantenimiento del orden público interior y la paz exterior; el debido respeto a la Instituciones y a las personas en la crítica de la acción política y administrativa; la independencia de los Tribunales, y la salvaguardia de la intimidad y del honor personal y familiar.

Esto habría la puerta a la arbitrariedad más absoluta: ¿qué era moral y qué no lo era? Los editores ya no sabían a qué atenerse, y debían correr el riesgo de sacar al mercado las revistas y luego ser sancionados si así lo creía oportuno el funcionario al cargo en ese momento. Manuel Vázquez Montalbán, director de Por Favor, escribió al respecto:

Por Favor ha vivido la época informativamente más difícil del franquismo [...] Con la Ley de Prensa la cosa se complicó [...] Pero el desmadre vino cuando los ministros aperturistas y no aperturistas se turnaban en un juego de bueno y malo que atontaba al profesional de la comunicación. ${ }^{1}$

\footnotetext{
1 Vázquez Montalbán, M. Sin título, en Por Favor n. o 100, año IV, 31 de mayo de 1975, p. 12.
} 
El artículo 2 de la "Ley Fraga" fue derogado en abril de 1977, cuando se aprobó el Real Decreto-Ley 24/1977 de Reestructuración de los órganos dependientes del Consejo Nacional y nuevo régimen jurídico de las asociaciones, funcionarios y patrimonio del Movimiento. Eso no impidió que la recién llegada El Jueves tuviera sus propios problemas con las autoridades, el más importante de los cuales fue el secuestro administrativo del número 7, en cuya portada podía leerse "Lefebvre se cisma en el Papa", y se veía a ambos combatiendo con sus báculos. A requerimiento del Juzgado de Instrucción número 3 de Barcelona se secuestra el n. ${ }^{\circ} 7$ de la revista, pero las demoras en el proceso hacen que solo queden cinco ejemplares cuando la policía acude a incautar la edición a las oficinas de $E l$ Jueves. ${ }^{2}$ En las páginas 12 y 13 del mismo número, además, aparecían varias fotografías a las que se les habían añadido bocadillos con ánimo jocoso. ${ }^{3}$ El Jueves, como otros semanarios satíricos del momento, no perdió la oportunidad de criticar a los sectores retrógrados de la Iglesia para apoyar a los reformistas, que en España, con el obispo Tarancón a la cabeza, habían sido un sector importante de presión contra el régimen franquista.

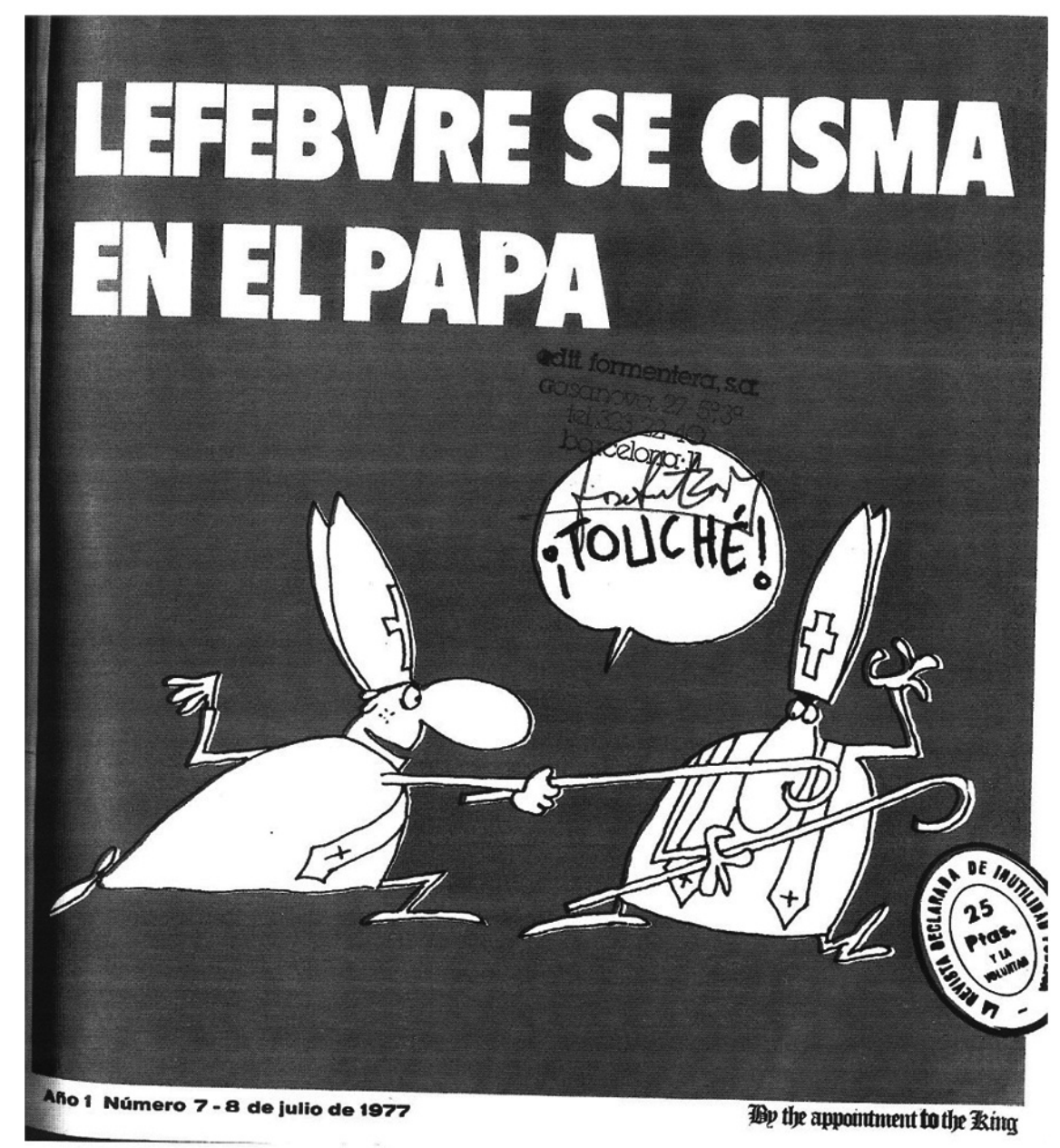

FIG. 1. Ilustración de cubierta de El Jueves n. 7 (8 de julio de 1977). Autor no acreditado.

\footnotetext{
2 Fontes, I., Menéndez, M.A. El parlamento de papel. Las revistas españolas en la transición democrática, vol. 1. Madrid, Asociación de la Prensa de Madrid, 2004, p. 579.

${ }^{3}$ Marcel Lefebvre fue un obispo de ideología ultraderechista opuesto a las reformas que impulsó el Concilio del Vaticano II, y que se enfrentó al Papa entre 1976 y 1977 por la ordenación de varios sacerdotes formados en su seminario, no reconocido por la Iglesia.
} 
De las cabeceras que podemos considerar principales - por cifras de venta, por calidad y por repercusión - El Jueves fue la última en aparecer. Cuando su primer número llega al mercado en mayo de 1977, la situación que se encuentra ya es, en cierta medida, de declive. Hermano Lobo, la primera en hacerle competencia a La Codorniz y aparecida en 1972, había tenido que cerrar en junio de 1976. La propia La Codorniz se encontraba en una precaria situación que la abocaría al cierre en 1978, incapaz de adaptarse a los nuevos tiempos y manteniendo hasta el final la bandera del humor blanco y apolítico. Por Favor, la más analítica e intelectual, gozaba aún de una relativa buena salud, pero también cerraría al año siguiente. Otras cabeceras secundarias como Muchas Gracias y Mata Ratos fundamentalmente, muy centradas en la fotografía erótica, sobrellevaron como pudieron las multas, secuestros y cierres administrativos pero ambas cerraron durante 1977, en junio y febrero respectivamente. La gran dominadora del sector en aquellos momentos era sin duda El Papus, que había aparecido en 1973 haciendo gala de un humor intencionadamente escatológico y provocador, muy alejado del clasicismo burgués de La Codorniz o del ingenio en ocasiones algo críptico de Hermano Lobo. La llegada del destape terminó de congraciar al semanario con el público, hasta el punto de que su difusión se calculaba, en 1976, en 230.000 ejemplares. $^{4}$

Por tanto El Jueves llega en un momento en el que el humor más clásico está en franca retirada, y la tendencia y gustos del público los marca El Papus. Pero aunque el periodo de máxima actividad había pasado, la nueva cabecera tiene aún que pugnar por un sitio con otras tres revistas: La Codorniz, Por Favor y El Papus.

\section{Los primeros números de El Jueves: el costumbrismo brugueriano.}

El Jueves, cuyo primer subtítulo fue La revista que sale los viernes, fue una iniciativa de José Ilario, un diseñador barcelonés que en su juventud había trabajado en la editorial Bruguera y que jugó un papel fundamental en la prensa de la transición. Estuvo en 1972 detrás de la fundación de Barrabás, una revista de humor deportivo iniciativa de los dibujantes Óscar Nebreda e Ivá, y que fue el antecedente directo de El Papus, en la que también cumplió funciones de edición. En 1974 lanza otra iniciativa personal: Por Favor. Su parte en la empresa se ve obligado a venderla por problemas ecónomicos con la distribuidora, ${ }^{5}$ y posiblemente fue eso lo que lo llevó a la creación de un nuevo semanario satírico. José Ilario reclutó para ello a tres dibujantes de otras publicaciones: Tom, Romeu y José Luis Martín.

Su intención fue editar una revista con menos textos que Por Favor, más ligera, sin demasiadas secciones de análisis o crítica, y sin mucho soporte fotográfico, de manera que el mayor atractivo de sus contenidos serían las historietas. Con un formato de $27 \times 36,5$ $\mathrm{cm}, 24$ páginas y un precio de 25 pesetas, también pretendía ser una alternativa más barata que sus competidoras. En el mismo mes, Por Favor costaba 45 pesetas y tenía 52 páginas, mientras que El Papus tenía un precio de 40 pesetas y 32 páginas. El interior era íntegramente en blanco y negro, pero la portada y contraportada eran siempre a dos tintas, mientras que las de las otras dos revistas eran a color, y también ofrecían páginas interiores en color, además de contar con mejor papel.

\footnotetext{
${ }^{4}$ Tubau, I. El humor gráfico en la prensa del franquismo. Barcelona, Editorial Mitre, 1987, p. 245.

${ }^{5}$ Fontes, I., Menéndez, M. A. Op. cit., p. 557.
} 
El director de El Jueves durante los números que voy a analizar fue José Luis Erviti, de quien Fontes y Menéndez afirman que "pone el carnet de periodista" — necesario para abrir una publicación de prensa-. Ángel Sánchez será el subdirector y Ángel Asensio, futuro subdirector de El Periódico de Catalunya, ocupa el cargo de redactor jefe . De la parte artística se ocupaban los dibujantes Romeu y Tom, que ya habían dirigido, brevemente, Muchas Gracias. En el consejo de redacción también aparece desde el inicio José Luis Martín, que a día de hoy sigue vinculado a El Jueves. El resto de los colaboradores del primer número son Ángel de la Font, Luis Vigil, Vives, Kim, Trallero, Don Ángel, Farreres, y el sueco Nitka. Los dibujantes son en su mayoría procedentes de otras publicaciones, un fenómeno que no es en absoluto nuevo: el trasvase de profesionales entre las diferentes revistas fue una tónica habitual a partir del momento en que se mutiplicó el número de las mismas.

En estos dubitativos números se aprecia ese intento por centrarse en la historieta que mencionaba antes, pero además también se crean personajes fijos bajo dos premisas: que representen diferentes estereotipos de la España del momento y que sean icónicos y reconocibles por el público, a la manera en la que lo eran los personajes infantiles de Bruguera, cuya herencia es obvia en estas historietas de una página con gag final. Entre ellas encontramos la caricatura del hombre de derechas ("Martínez 'el Facha" de Kim), la del de izquierdas ("Pepe Progre" de Tom), del clero ("El padre Cirilo" de Vives), del empresario ("Don Tristan Vallejo y Riuet" de Romeu), de la mujer liberada ("Betty" de Romeu), del oficinista ("Leopoldo, un oficinista que es el colmo" de José Luis Martín), del funcionario ("El funcionario neura" de Don Ángel), del ligón barato ("Rodolfo Valentín siempre va caliente" de José Luis Martín) y ambientes típicos: el bar ("El bar de Paco" de Tom) y el cortijo andaluz ("El cortijo del señorito" de Trallero). En el n. ${ }^{o} 1$ aparecen hasta once series con vocación de ser fijas, de las que no sobreviven demasiadas a estos primeros tiempos de ensayo y error. Las que caen son rápidamente sustituidas por otras, hasta que poco a poco se va configurando un conjunto atractivo y contundente de cara a los lectores, del que surgen auténticos clásicos del semanario.

“Martínez 'el Facha” es la primera sección de historieta fija que encontramos al abrir el primer número de El Jueves, y también es la única de toda esta época que se publica en la actualidad. La obra de Kim comienza con un personaje que es reminiscencia del régimen que estaba aún finiquitándose, y sus actitudes parodian y denuncian la pervivencia de una moral y una manera de ver el mundo fascistas. En su primera aparición ${ }^{8}$ Martínez aparece como un viejo calvo, con bigote, traje y gafas de sol, look que va a mantener con ligeros cambios de diseño durante toda su trayectoria. En esa primera historia, recibe un regalo de un amigo al que ha enchufado de conserje: una botella de coñac. Esta es una de las claves del personaje: el clientelismo, el intercambio de favores y la corrupción generalizada de la clase política proveniente del franquismo. Acto seguido Martínez descubre a su hijo bippie fumando un porro, y comienza a abroncarle mientras el chaval permanece impasible por el globo que lleva. Enfadado, Martínez bebe y bebe de la botella de coñac y acaba tirado en el suelo borracho y contando batallitas de los tiempos gloriosos. El contraste entre Martínez y sus hijos modernos es un tema recurrente en las primeras entregas, pero pronto Kim va centrándose en la sátira de la clase política adicta al régimen y desarrolla

\footnotetext{
6 Ibid..

7 En el título de esta serie se hace más evidente la herencia de Bruguera, al homenajear la rima habitual de las series infantiles de la veterana editorial.

8 Kim. "Martínez, 'el Facha”, en El Jueves n.o 1 (27 de mayo de 1977), p. $2 .$.
} 
una tesis central: la ausencia de ideales reales por parte de ese grupo político. Los hombres de la vieja guardia son representados como amorales y oportunistas, y lo que buscan no es el bien de España, sino su propio bienestar. De lo que se trata es de vivir bien, de colocarse en un puesto que permita ganar un buen sueldo y mantener sus privilegios sociales en el nuevo sistema político. Y para ello no tienen reparos en cambiarse la chaqueta o afiliarse a partidos demócratas, incluso de izquierdas. ${ }^{9}$ Kim dibuja a Martínez como "el último español íntegro", aferrado a sus ideales y presa de la nostalgia de tiempos mejores -incluso con simulacros de campañas militares-. Es un hombre fuera de época, rídiculo por tanto, al que todo le sale mal en su intento de preservar España de los vientos de cambio, que le pasan por encima una y otra vez. En algunas entregas se encuentran interesantes citas a la actualidad, como la ya mencionada del n. 8 de la revista, en la que Martínez se indigna por la desaparición de la mitad de los ministerios porque dejará sin

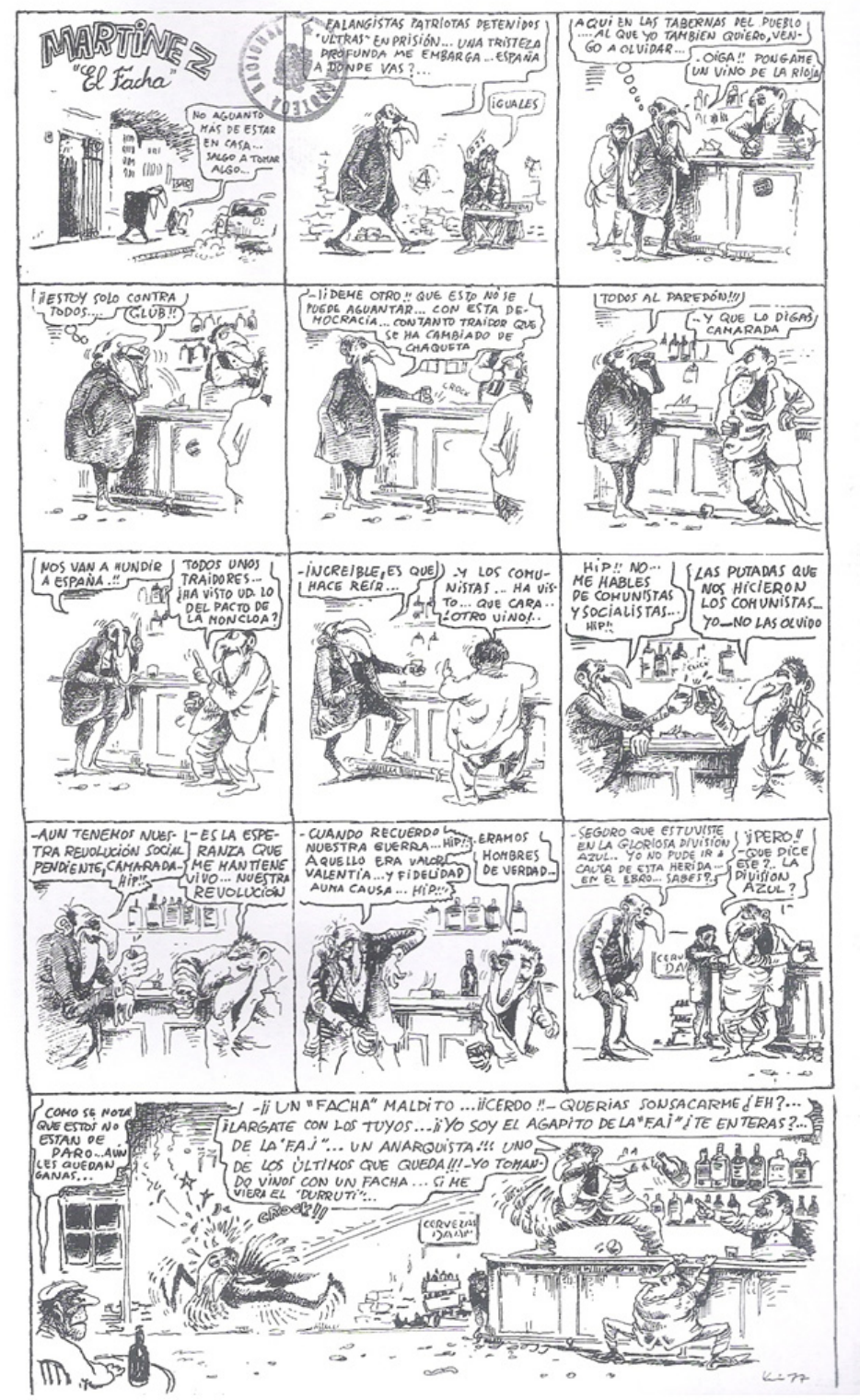

FIG. 2. Kim. "Martínez 'El Facha”, en El Jueves n. 24 (4 de octubre de 1977), p. 3 .

\footnotetext{
9 Dos buenos ejemplos de este comportamiento podemos encontrarlos en Kiм. "Martínez (el Facha)", en El Jueves n.o 8 (15 de julio de 1977), p.3 y Kim. "Martínez (el Facha)", en El Jueves n. 4 (17 de junio de 1977), p. 2.
} 
trabajo a muchos camaradas. Otro excelente ejemplo es además la página más brillante de "Martínez 'el Facha" que he encontrado en esta etapa. Martínez, sintiéndose deprimido por el rumbo que toma España, entra en una taberna, y allí comienza a hablar con otro hombre en los mismos términos: descrédito de la democracia, revolución social, ataques a socialistas y comunistas, etc. En las viñetas finales, Martínez le comenta a su nuevo amigo que está seguro de que, dado su valor, estuvo en la División Azul. Su contertulio monta entonces en cólera... porque resulta ser un viejo combatiente anarquista.

Otra de las secciones que permanece fija durante toda esta etapa, aunque con numerosas variantes en su título, es la que debuta en el n. 1 como "El cortijo del señorito", de Trallero. Se trata de una historieta a doble página en la que se desarrolla el universo de la política rural, con sus pucherazos, sus cacicadas y, en suma, una reproducción en microcosmos de la política a gran escala, con personajes intencionadamente parecidos a Suárez o Fraga. Más allá de eso, es interesante comprobar que Trallero deforma el lenguaje para

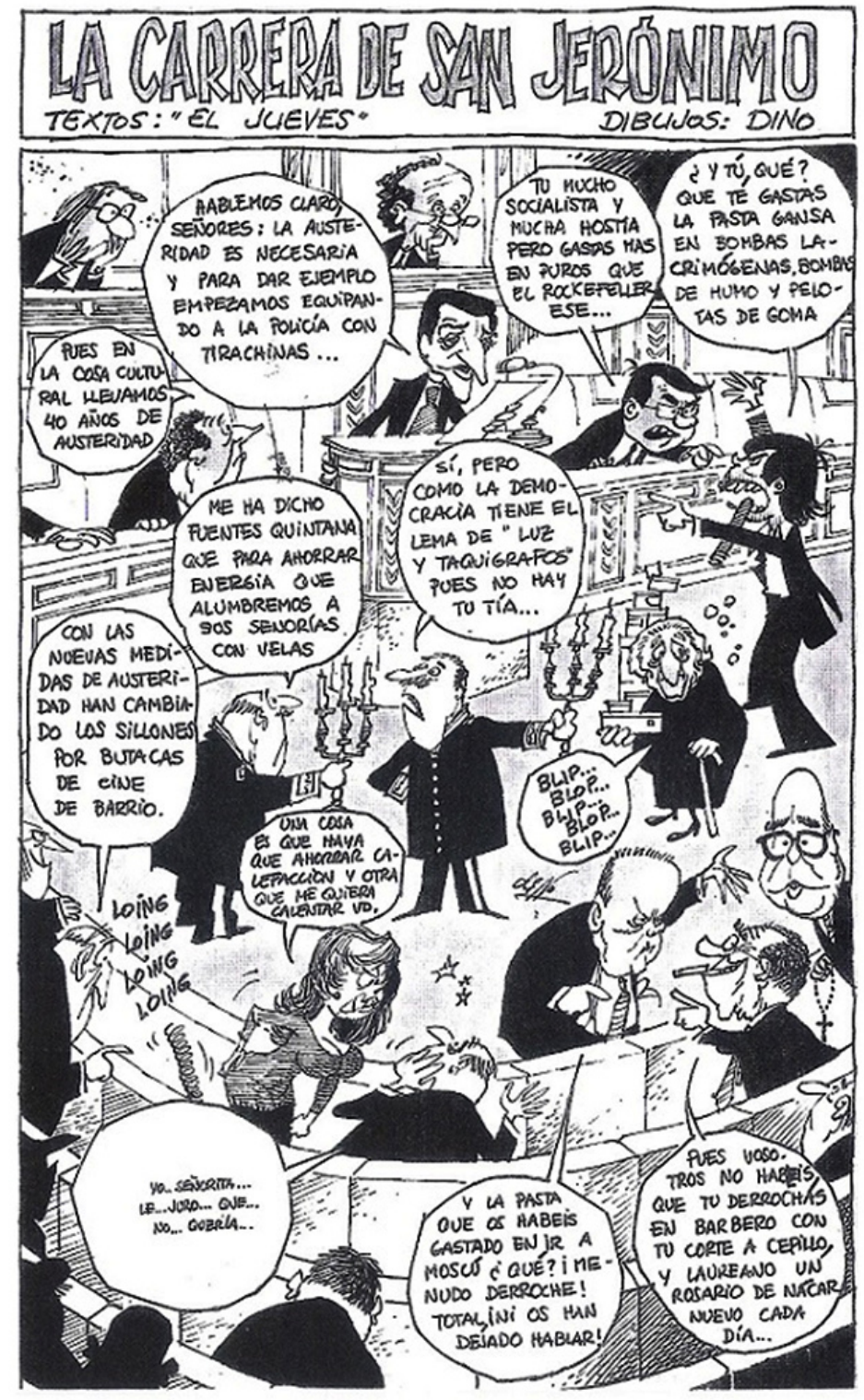

FIG. 3. Dino y El Jueves. "La carrera de San Jerónimo", en El Jueves n. 25 , p. 9. 


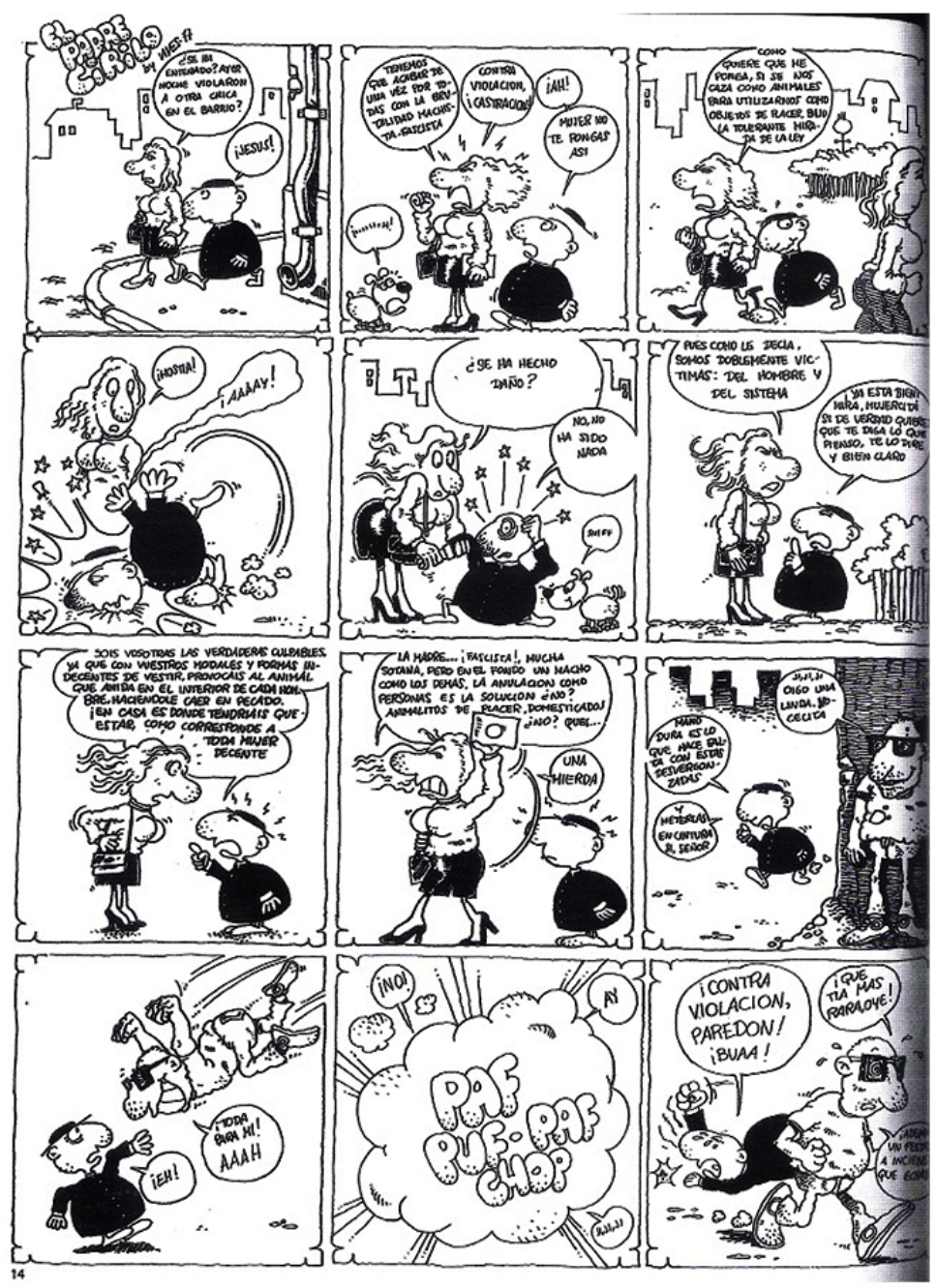

FIG. 4. Vives. "El padre Cirilo", en El Jueves n. 20 (7 de octubre de 1977), p. 14.

reproducir la fonética del sur de España en la línea de lo que ya habían empezado a hacer autores como Ivá o Já en El Papus. El especialista Santiago García ha señalado la influencia del autor mexicano "Rius" y su serie Los Supermachos en el trabajo de Trallero. ${ }^{10}$

"Betty" es la sección más estable de Martín Romeu. Aparece en todos los números salvo uno hasta su desaparición en el n. ${ }^{\circ}$ 23. Su protagonista es el prototipo de mujer liberada, pero pasado por un tamiz masculino: Betty es frívola, algo ingenua en asuntos sexuales, y aunque hace suyo el discurso feminista del momento, lo interpreta de una manera pueril y superficial. Siempre acaba desnudándose total o parcialmente, hasta el punto de que se queja a su creador del asunto, en llamativos ejercicios metaficcionales. ${ }^{11}$

"El padre Cirilo", de Vives, es otra sección que aparece durante un periodo prolongado: desde el n. ${ }^{\circ} 1$ al 25, justo antes de los cambios en el semanario que tomo como referencia para cerrar la primera etapa. El personaje es objeto de una evolución interesante. En las primeras entregas es un sacerdote de parroquia pequeña bienintencionado y despistado,

${ }^{10}$ García, S. "Supermachos”, en Mandorla, 2 de diciembre de 2010, disponible on line en http://santiagogarciablog.blogspot.com.es/2010/12/supermachos.html

11 Romeu, M. “Betty”, en El Jueves n. 11 (5 de agosto de 1977), p. 5. 
que simplemente no es capaz de asimilar los rápidos cambios sociales que están teniendo lugar. Pero a medida que se publican sus historias Vives afila la sátira, y va convirtiendo a Cirilo en un sacerdote conservador e hipócrita, que no puede evitar mirar con gusto una revista pornográfica requisada ${ }^{12}$ pero que es agresivo y hasta cruel con aquellos que defienden esos cambios sociales. Manolo, un obrero comunista, le da la réplica y sufre en sus propias carnes tanto la represión policial ${ }^{13}$ como la de la ultraderecha. ${ }^{14}$ La historieta más negra de "El padre Cirilio" le muestra culpando agresivamente a las mujeres de sus violaciones, por no quedarse en casa, para acabar él mismo violado — en elipsis — por un violador corto de vista que confunde su sotana con una falda. ${ }^{15}$

En una de las entregas de la serie Vives parece señalar que, pese a todo, semejante actitud mezquina es responsabilidad del clero y no de la fe en sí misma: tras ignorar Cirilo la represión violenta de manifestantes, el hambre en las calles y el alza de precios, monta en cólera al descubrir que en la playa hay una pareja haciendo el amor. El padre llama a la Guardia Civil, que pone fin al acto, ante lo cual Cirilo se marcha relajado y satisfecho por velar "contra la inmoralidad del país en todo momento". La respuesta que recibe desde las alturas — de Dios, por tanto — no puede ser más contundente: un sonoro "Jilipollas" $[\mathrm{sic}]{ }^{16}$

\section{El giro hacia el humor político.}

Aunque eso no signifique que la crítica política no aparezca con frecuencia, el costumbrismo predomina en los primeros números de la revista. Las alusiones a esta cuestión aparecen como parte del reflejo de la sociedad en casi todas las secciones, pero no hay historietas específicamente dedicadas al comentario de la actualidad política. El Papus y Por Favor estaban mucho más politizadas — cada una desde una óptica muy diferenteSin embargo El Jueves casi siempre dedicaba su ilustración de cubierta a una noticia de actualidad política, y varias de las secciones de textos la trataban. Por ejemplo, Ángel de la Font firmaba "Mac Sánchez y esposa", que ficcionaba un diálogo matrimonial, franquista él y progre ella, en el que discutían de la actualidad. Ya en el primer número un texto firmado por Mar Fontcuberta titulado "Elecciones y diarrea" posiciona El Jueves en el espectro político. ${ }^{17}$ En el texto se critica abiertamente a la derecha calificada de franquista - Alianza Popular, Acción Nacional o FET de las JONS - pero también, y es muy significativo, a Adolfo Suárez y la UCD, que se incluyen en la categoría de "los prácticos, o neofranquistas". Recordemos que la UCD es el partido que ganaría en las inminentes y primeras elecciones, y que pretendía presentarse como una alternativa moderada y de centro frente al resto de fuerzas políticas. En su texto Fontcuberta acusa: "Les parece feo seguir como hace cuarenta años y creen que hay que ponerse a tono con lo que se lleva hoy en día [...] La mayoría de sus líderes también han sido ex ministros, directores generales y demás cargos, y hay uno que sigue siendo presidente". En la sección de "Cartas

\footnotetext{
${ }^{12}$ Vives. "El padre Cirilo", en El Jueves n. ${ }^{\circ} 6$ (1 de julio de 1977), p. 5.

13 Ibíd. "El padre Cirilo, Está siempre hecho un lío", en El Jueves n. ${ }^{\circ} 19$ (30 de septiembre de 1977), p. 14.

${ }^{14}$ Ibid. "El padre Cirilo. Está siempre hecho un lío”, en El Jueves n. 15 (2 de septiembre de 1977), p. 8.

15 Ibid. "El padre Cirilo", en El Jueves n. 20 (7 de octubre de 1977), p. 14.

16 Vives. "El padre Cirilo. Está siempre hecho un lío”, en El Jueves n. 16 (9 de septiembre de 1977), p. 8.

17 Fontcuberta, M. “Elecciones y diarrea”, en El Jueves n.o 1 (27 de mayo de 1977), pp. 4-5.
} 
al director" - donde las misivas eran ficticias - la revista también se posicionaba a favor de la amnistía general a los presos políticos, uno de los caballos de batalla de la oposición democrática al régimen. ${ }^{18}$

A partir de cierto momento la revista asume una posición cada vez más beligerante y comprometida. Es aventurado afirmar sin pruebas si este proceso se debió a un compromiso político o a una necesidad de renovación motivada por unas ventas bajas, por supuesto, aunque es cierto que el modelo de El Jueves, que podríamos definir en buena medida como una adultización de las revistas de Bruguera, se alejaba de la tónica de las revistas que dominaban entonces el mercado. Este giro no hará otra cosa que acercarla a las mismas, especialmente a El Papus.

Progresivamente, las historietas costumbristas van desapareciendo. "Pepe Progre" de Tom ve su última entrega en el n. ${ }^{\circ}$ 4. "Leopoldo (un oficinista que es el colmo)" y "Rodolfo Valentín siempre va caliente" de José Luis Martín terminan en el n. ${ }^{\circ}$, al igual que "E1 bar de Paco" de Tom. "El funcionario neura" de Don Ángel concluye en el n. o 6, y "Don Tristán Vallejo y Riuet” de Romeu en el n. ${ }^{\circ} 10$.

Ninguno de estos autores deja de colaborar con la revista, sino que reconducen sus páginas a un modelo mucho más cercano al de El Papus: secciones de humor político y crítico sin personajes fijos, que permitan tratar cada semana una noticia o tema diferente. En esta línea, José Luis Martín alternó a partir del sexto número del semanario "Historias de ciencia-ficción" y "Diario íntimo de...". En la primera dibujará, entre otras, historias sobre las acciones de la ultraderecha, ${ }^{19}$ y satirizará a las principales figuras políticas del momento. La segunda sigue de hecho la misma mecánica, y en ella imagina la vida privada de diferentes personajes reales de la política española, como Felipe González, pero también de estereotipos como "la feminista radical", ${ }^{20}$ "el líder ultra" ${ }^{21}$ o "el inspector de hacienda". 22 En el n. ${ }^{\circ} 25$ debuta el que acabaría siendo su personaje más popular, Dios, en una sección con el título de "El Señor esté con nosotros".

Romeu fue alternando varias series de carácter efímero hasta encontrar un nuevo rumbo, recuperando a los personajes infantiles que había empleado en otros semanarios. Entre los números 20 y 23 dibuja "Nuevas aventuras de la 'Liga de los sin bata", y a partir del n. 24 retoma una serie que realizó en Por Favor previamente: "Los hijos de su madre". En ambas Romeu juega a la analogía entre las andanzas infantiles y la actualidad política del país.

En el caso de Tom, pasa a realizar una sección fija a doble página o a página y media, normalmente situada al inicio de la revista, en las páginas 5 y 6 , donde trata algún tema de actualidad, aunque no necesariamente política: turismo, crisis ecónomica, la paternidad,

18 "Un crizado", en "Cartas al director", en El Jueves n.o 1 (27 de mayo de 1977), p. 18.

${ }_{19}$ Martín, J.L. "Historias de ciencia-ficción”, en El Jueves n. 6 (1 de julio de 1977), pp. 8-9.

20 Ibid. "Diario íntimo de una feminista radical", en El Jueves n. ${ }^{\circ} 21$ (14 de ocutbre de 1977), p. 9.

${ }^{21}$ Ibid. "Diario íntimo de un líder ultra", en El Jueves n. ${ }^{\circ} 22$ (21 de octubre de 1977), p. 9.

${ }^{22}$ Ibid. "Diario íntimo de un inspector de hacienda (drama)", en El Jueves n. 11 (5 de agosto de 1977), pp. 8-9. 
etc. A partir del n. 19 la sección adquiere título fijo: "Desinforme semanal", en obvia alusión al programa de RTVE Informe semanal, en antena desde 1973.

Además, aparece un nuevo colaborador, Dino, otro pseudónimo de un dibujante adscrito a la Escuela Bruguera cuyo verdadero nombre es Joan Rafart i Roldán, pero que firmó la mayor parte de su obra como Raf. Su trabajo será ilustrar una sección fija que debuta en el n. ${ }^{\circ}$ : "La carrera de San Jerónimo", una sátira del día a día del Congreso de los Diputados, donde los políticos del momento se enfrentan entre sí y la parodia alcanza a todos los partidos. Los diálogos de esta página aparecen firmados en la mayoría de los casos por El Jueves, así que podemos deducir que el autor es colectivo.

Con estos cambios El Jueves giraba decididamente hacia la sátira política en sus viñetas, apuntaladas por nuevas secciones de texto que se unen a las ya existentes, por ejemplo una columna fija del director, José Luis Erviti, sobre la actualidad parlamentaria que acompañará en un principio a la historieta de "La carrera de San Jerónimo". Otros colaboradores, como Luis Vigil y Ángel Sánchez escribieron columnas de opinión casi siempre centradas en política o cuestiones sociales.

Pero a pesar del giro politico de la revista, también fueron apareciendo secciones con nuevas temáticas. Las más significativas fueron "Manolo, marca ya”, sobre actualidad deportiva, a cargo de los periodistas especializados Emilio Pérez de Rozas y Martín Perarnau, "Prensa cardiológica", sobre noticias del corazón, por José María Bachs, y "Consultorio Íntimo y Sexual", una sección de preguntas y respuestas simuladas sobre sexo, firmada por "el Hon. Profesor Max de Max. Sexólogo por la universidad de Pekín" y acompañada con ilustraciones de Vives. Como derivado de esta sección surgirá en el n. ${ }^{\circ} 29$ una de las secciones de cómic más conocidas y longevas de El Jueves, "El Profesor Cojonciano", de Óscar Nebreda, que presenta a Cojonciano como un ayudante de Max de Max.

\section{Crónica de un desengaño: la decepción tras las primeras elecciones generales.}

A partir del momento en el que el espacio dedicado a la política, tanto en historietas como en textos, se incrementa de manera sustancial, el humor que se emplea para tratarla se va endureciendo. E1 hito que marca el cambio es la celebración de las primeras elecciones generales en democracia, el 15 de junio de 1977, momento en el que se habían publicado solo tres números de El Jueves. En esos comicios, la UCD de Adolfo Suárez fue la fuerza política más votada con más de seis millones de votos. Fue un duro golpe para las aspiraciones de la izquierda, a pesar de que las condiciones previas a las elecciones no favorecían sus candidaturas - el PCE había sido legalizado tan solo dos meses antes, en abril-. E1 PSOE había obtenido buenos resultados - más de cinco millones de votos- pero la sensación que predominó fue la de que, en el primer ensayo de democracia, la sociedad española había apostado por una fuerza reformista pero continuista con el antiguo régimen - recordemos que El Jueves calificaba a la UCD como "neofranquista"-. En los medios críticos de izquierda, en los que incluyo a todas las revistas satíricas del momento, esto supone varias cosas. La primera, que comienza a cundir el escepticismo hacia esta democracia. No hacia la democracia como sistema abstracto, sino hacia esta en concreto, hacia la manera en la que se estaba haciendo la transición. La primera portada de El Jueves tras las eleccio- 


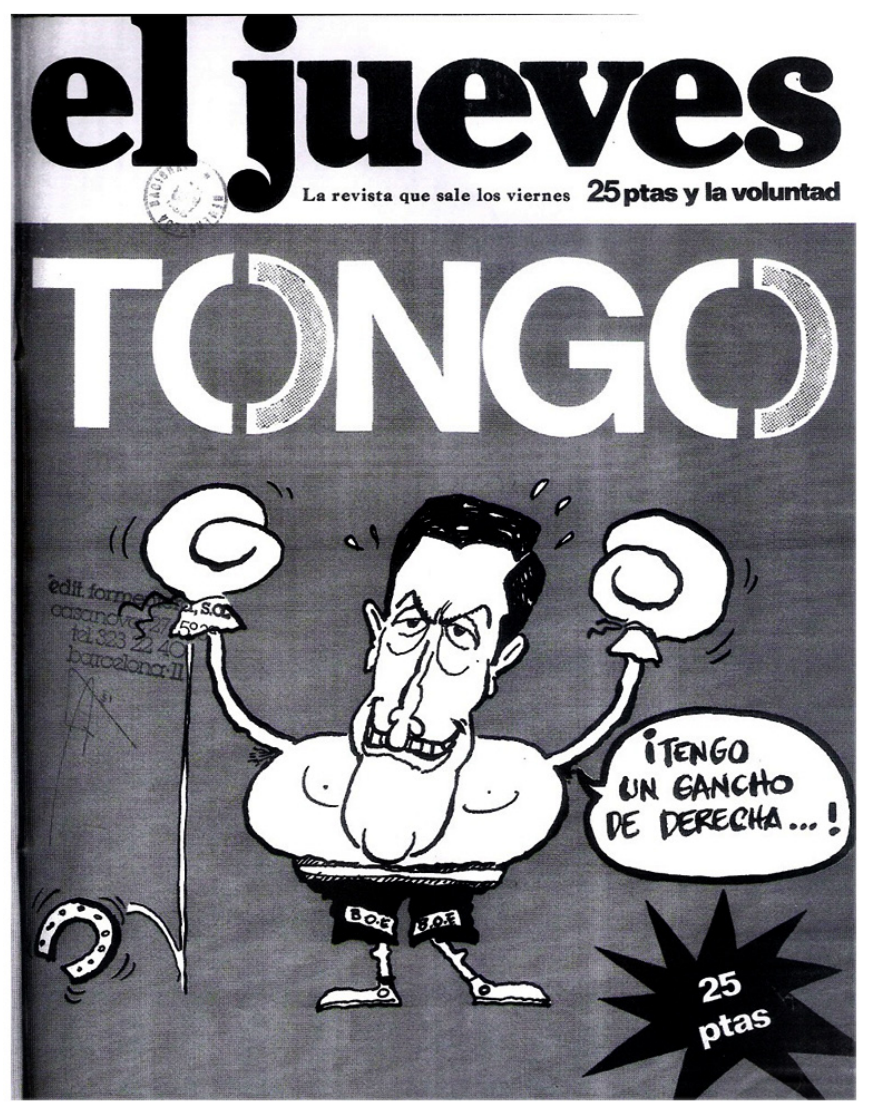

FIG. 5. Autor no acreditado. El Jueves n. 4 (17 de junio de 1977), cubierta.

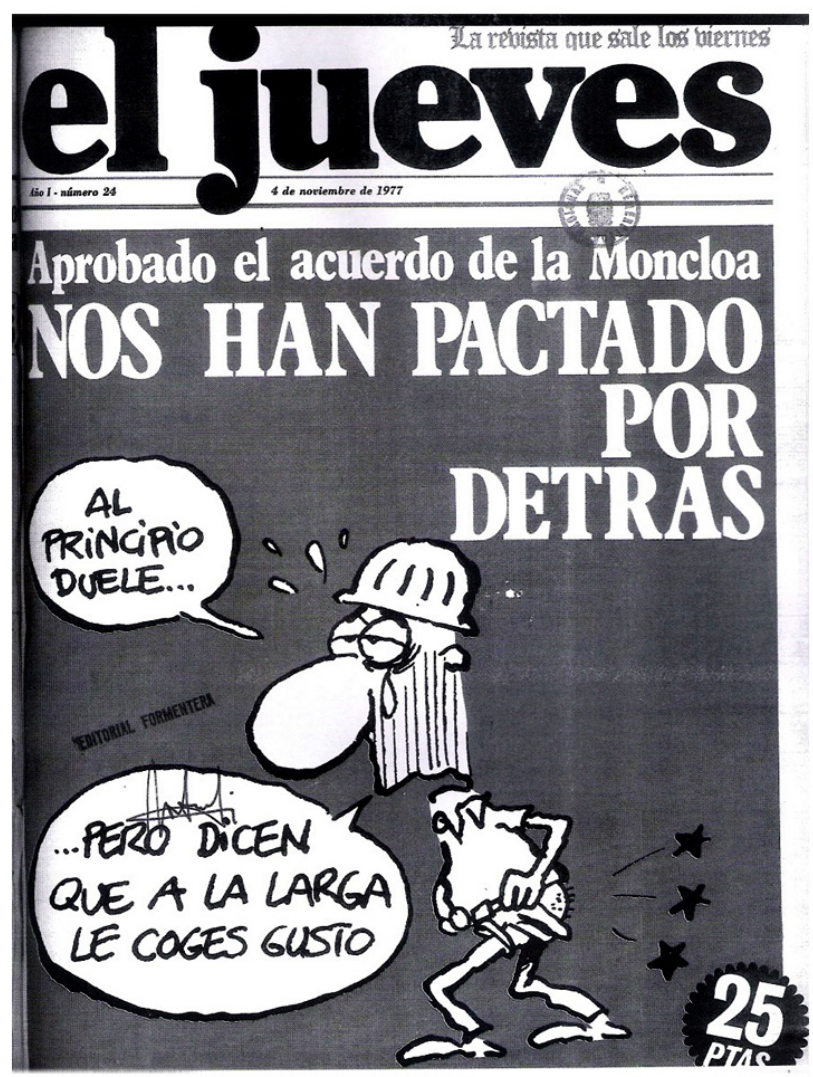

FIG. 6. Autor no acreditado. El Jueves n. 24 (4 de noviembre de 1977), cubierta. 
nes, la del cuarto número, titulada con un rotundo "Tongo", muestra a Suárez como un boxeador victorioso, jactándose de su gancho de derecha mientras una herradura cae de uno de sus guantes.

El desencanto hacia el rumbo que está tomando la construcción de esta primera democracia queda aún más patente con la explícita portada que aludió a los Pactos de la Moncloa.

La portada dirige nuestra atención al obrero al que se le escapa una lágrima mientras se sube los pantalones, tras ser pactado por detrás. Es decir, el acuerdo se ha aprobado a espaldas del trabajador - o el pueblo-, y lo han aprobado solo ellos — sujeto elíptico del titular-, es decir, los políticos. Los pactos de la Moncloa fueron dos acuerdos, uno de corte económico y otro político, que suscribieron prácticamente todas las fuerzas políticas y, pasado un tiempo, CCOO y UGT; solamente la CNT se negó a firmarlo. Estos acuerdos fueron la respuesta del gobierno a la profunda crisis económica que vivía el país como consecuecia de la crisis mundial del petróleo de 1973. En 1977 la inflación anual era del $30 \%$, y el porcentaje de población activa sin empleo era de un 6,6\%. ${ }^{23}$ En su columna de ese mismo número, Erviti alude a esto empleando una alegoría en la que los pactos serían un hijo que acaba de ser dado a luz. Los diferentes políticos serían el "equipo médico", pero, a partir de ahora, "todos tendremos que darle el biberón". "El hecho consumado es la única forma de imponerse en este país". ${ }^{24}$ Es la primera vez que el semanario escenifica de manera tan explícita el divorcio entre poder político y ciudadanía, y la primera vez que aparece esa idea, hoy en el centro de la crítica a la transición, de que el proceso fue dirigido desde arriba hacia abajo, sin una participación ciudadana significativa, o, al menos, dentro de las expectativas que los desencantados responsables y autores de El Jueves habían depositado en sus alternativas democráticas.

Las críticas a los partidos de izquierda pueden sorprender en un primer acercamiento a la revista. Se deben en primera instancia al marco de sátira generalizada que define a $E l$ Jueves, que lleva implícito la ausencia de bula para cualquier actor del panorama político. Esto es algo muy evidente en la sección de "La carrera de San Jerónimo", pero es igualmente palpable en el resto, hasta el punto de que las críticas y bromas hacia las diferencias formaciones políticas y sus cabezas visibles mantienen siempre una proporción similar. ¿Podemos considerar esto como una prueba de neutralidad política del semanario? Bajo mi punto de vista, no. Sería un error inferir de la falta de tabúes de sus colaboradores y de sus críticas equitativas una falta de posicionamiento político. El Jueves, ideológicamente, era claramente de izquierdas, aunque no tomara partido por ninguna de las fuerzas políticas de la transición. Era de izquierdas en tanto que mantenía posturas progresistas, abogaba por la apertura democrática, la desmilitarización de la sociedad y el pacifismo, y asumía como propias la mayor parte de las reivindicaciones de la oposición democrática al régimen: la amnistía política ${ }^{25}$ la exigencia de derechos como el de libre asociación, el antiamericanis-

${ }^{23}$ SuÁrez,J. "Los Pactos de la Moncloa o el triunfo de la concordia”, en Historia y vida n. 355 (1997), p. 29.

${ }^{24}$ Erviti, J. L. “¡Un niño!”, en El Jueves n. 24 (4 de noviembre de 1977), p. 15.

${ }_{25} \mathrm{Al}$ respecto de la amnistía hay un texto muy significativo firmado por Ángel Sánchez en El Jueves n. 22 (21 de octubre de 1977), p. 3:

\footnotetext{
Nuestra capacidad de reconciliación es tan grande que pasamos a amnistiar seguidamente a todos esos señores cuyos nombres golpean nuestra memoria. Podríamos poner alguna que otra condición como la de que Franco, Fraga y Martín Villa (por citar sólo una representación no exhaustiva, evidentemente) hagan ofrenda de una corona de flores a todos los verdaderamente caídos por la democracia.

Una corona que dijese algo así: "Amnistía, tus muertos no te olvidan." Pero como somos mejores que ellos, los amnistiamos sin condiciones. Fíjense en un Samaranch, por ejemplo, con el pasado franquista que tiene a sus espaldas...
} 
mo, etc. Pero la plasmación práctica de dicha ideología era otra cuestión. El Jueves, como El Papus, no era una publicación de teoría política, sino que se dedicaba a la parodia de actualidad. Y es aquí donde entra en juego el desengaño que se vivió tras las primeras elecciones y, sobre todo, tras los pactos de la Moncloa. Pedro Pérez del Solar ha tratado ampliamente el concepto del desencanto aplicado a la política y a las revistas de cómic adulto de los años ochenta. ${ }^{26} \mathrm{El}$ desencanto consistió, siguiendo su estudio, en la pérdida de ilusión de parte de la sociedad española acerca de la posibilidad real de llevar a cabo un cambio socioeconómico radical y " [al] limitarse a un rol de consumidor de las múltiples ofertas del presente [...] el 'desencantado' no sólo dejaba amplia impunidad a la tan rechazada clase gobernante, sino que favorecía sus planes de expansión económica”. ${ }^{27}$ Pérez del Solar, no obstante, señala con acierto que el desencanto comienza ya en los primeros compases de la transición, motivada por las renuncias de las fuerzas de izquierda, la pervivencia de prácticamente todos los activos políticos y económicos del franquismo y la manera en que las fuerzas políticas manejaron la transición: "El espacio de debate público fue reemplazado por su representación mediática [...]. La democracia se volvió algo que ocurría en la televisión y en las revistas; un espectáculo para ser observado pasivamente". 28 "Pasivamente" es la palabra clave para entender esta tesis crítica con la transición, que entronca con el reciente concepto de "Cultura de la Transición" o "CT", desarrollado ampliamente en la antología de ensayos CT o la Cultura de la Transición. Crítica a 35 años de cultura española. La CT pretende ser una herramienta de crítica cultural que señale los límites que la transición, en aras del consenso, impuso a la producción cultural del país, cuyas instituciones apoyaron y estimularon la cultura políticamente neutra o inane, encauzada en unos estrechos márgenes.

La cultura, de hecho, está notoriamente desactivada como tal en 1977, cuando, ante el silencio de la cultura y sin mecanismos culturales de crítica, se producen los Pactos de la Moncloa, primer pacto oficial del Franquismo con la oposición, que supuso la eliminación de los movimientos sociales y el abandono de propuestas democráticas más amplias — como, snif, la democracia económica-. El abandono, vamos, de lo que había sido la izquierda del interior en los últimos años del Franquismo. ${ }^{29}$

Así, durante los años ochenta se potencia una cultura vertical, "una gigantesca máquina propagandística [...] de un sistema político". ${ }^{30}$ La cultura y los medios de comunicación asumen los cauces de lo aceptable impuestos desde arriba y se evita a toda costa el conflicto y el cuestionamiento del sistema. La transición se consagra como un proceso modélico y las renuncias y pactos que se llevaron a cabo en su marco se interpretan en clave de consenso.

Ante esta superestructura construida a marchas forzadas, muchos agentes culturales abrazaron el desencanto y se desactivaron políticamente, y lo mismo sucedió en el conjunto de la población. Pérez del Solar da en su estudio sobrados ejemplos de llamadas a la vida lúdica desde los medios, a olvidarse de los rancios ideales de los sesenta y setenta

\footnotetext{
26 Pérez Del Solar, P. Imágenes del desencanto. Nueva historieta española. 1980-1986. Madrid, Iberoamericana / Vervuert, 2013.

27 Ibid, p. 16.

28 Ibid, p. 13.

${ }^{29}$ Martínez, G. "El concepto CT", en CT o la Cultura de la Transición. Crítica a 35 años de cultura española. Madrid, DeBolsillo, 2012, p. 15.

30 Ibid, p. 17.
} 
y disfrutar de la vida. La batalla está ganada, y ahora toca dejar la lucha y disfrutar de lo logrado. ${ }^{31}$

Pero hubo otra vía para canalizar este desengaño, que se manifiesta desde el principio, desde los primeros pasos de la transición, y que consistió en rebelarse contra ella y denunciar sus desequilibrios y los olvidos que institucionalizó. Desencantados con lo que se interpretaban como las renuncias de los partidos de izquierda con el fin de entrar en el juego político, y con la impunidad de los partidos emanados directamente del régimen franquista, las revistas satíricas parecen aferrarse al idealismo y manifiestan cierto sentimiento de traición: de la derecha ya sabían lo que podían esperar, pero sus expectativas e ilusiones por parte de la izquierda eran diferentes a las que se plasmaron en la política real. Por eso no es sorprendente que las burlas dirigidas hacia Felipe González y sobre todo a Santiago Carrillo fueran en ocasiones incluso más ácidas que las que golpeaban a Suárez, Fraga o Martín Villa.

Ya en el segundo número de la revista vemos una caricatura de Dolores Ibárruri en la portada que declara sonriente que "Carrillo es un facho". E1 texto de la cubierta reza "Pánico en el P.C.E." y "La Loles no se aprende el papel”. Para entender el desencanto plasmado en las revistas tenemos que atender a la deriva ideológica del PCE. Ya en 1956 adoptó la fórmula de la Reconciliación Nacional y renunció a la lucha armada. Cuando muere Franco, el comunismo parte como la fuerza más sólida de todas las que conformaban la oposición antifranquista, ${ }^{32}$ y de hecho durante 1976 "el partido intentó imponer su ideal rupturista mediante una dinámica de movilización controlada, a cargo, principalmente, de las Comisiones Obreras". ${ }^{33}$ Pero a partir del momento en el que es evidente que esa vía no fructificará, el PCE “rebajó sus objetivos máximos y [...] centró sus esfuerzos en lograr algún tipo de negociación con las élites procedentes del franquismo que se hallaban en el poder". ${ }^{34}$

Carrillo lideró a partir de entonces una política de progresivo distanciamiento de la órbita soviética y acercamiento al eurocomunismo, con el fin de presentar una imagen de partido democrático y, más concretamente, para poder concurrir en las primeras elecciones generales, objetivo que se consigue prácticamente en el último momento: la legalización del partido tuvo lugar en abril y las elecciones se celebraron el 15 de junio. Entre ambos sucesos, Carrillo publicó Eurocomunismo y Estado. En este trabajo articuló su crítica del régimen soviético, del que escribió que no era un verdadero sistema socialista. Negro sobre blanco, Carrillo se divorciaba de la ortodoxia comunista y concretaba un nuevo paradigma para el PCE, madurado durante los años previos y más cercano a la socialdemocracia: un comunismo que miraba a la Europa democrática más que a la URSS. De hecho, ya en 1972 el PCE abogaba por la integración en la CEE. ${ }^{35}$ Tras las elecciones generales, Carrillo y el partido continuaron con esa política legitimadora y renovadora y se apostó por el consenso desde su posición de tercera fuerza política más votada — con un 9,2\% de los votos-, ya

\footnotetext{
31 En el capítulo quinto de Imágenes del desencanto..., titulado "Cosas de políticos: 'Olvidar los sesenta”, pueden encontrarse numerosos ejemplos del discurso desactivador de ciertos medios y teóricos.

32 Treglia, E. “Un partido en busca de identidad”, en Historia del presente n.o 18 (2011/2), 2. a época, p. 26.

33 Ibid.

34 Ibid.

35 Ibid., p. 27.
} 
que pretendía que aquella situación desembocara en un gobierno de concentración democrática, dada la igualdad de UCD y PSOE, cosa que como sabemos nunca sucedió. ${ }^{36}$

En ese contexto el PCE aceptó y firmó los pactos de la Moncloa a los que tan rotundamente aludía la portada del n. ${ }^{\circ}$ 24. Sigo en este asunto a Treglia: en su opinión, el PCE apoyó los pactos porque preveía "una ampliación de la intervención estatal y una reestructuración del gasto público que [...] creaban las premisas para una progresiva socialización de la producción” ${ }^{37}$ ¿Cómo se explica, entonces, la postura de El Jueves y otros semanarios, por qué no fueron comprensivos con las decisiones de la izquierda? Es simple: los pactos de la Moncloa implicaban despidos y duros recortes salariales. Y ante esta situación la revista se alineó con los más desfavorecidos y cargó contra todos los firmantes, pero especialmente con los de izquierda.

Esa traición a los ideales comunistas fue la fuente de gran parte de las críticas hacia el dirigente del PCE. José Luis Martín dibujó en su sección de "Historias de ciencia-ficción" un repaso a un día cualquiera en la vida de Carrillo, en la que sufre un par de atentados de la KGB - en alusión a su desencuentro con el partido comunista soviético一, se hincha a comer - “HHay que ver como saben comer estos burgueses de mierda!”-, se niega a levantar el puño porque hay fotógrafos presentes, y reza cuatro veces al día. ${ }^{38} \mathrm{La}$ broma de presentar a un comunista como un devoto cristiano se repite varias veces en estos primeros números de El Jueves, y puede entenderse, porque el contraste entre teoría y práctica es un mecanismo básico del humor: si se trata de exponer las contradicciones de Carrillo y sus excesivas concesiones a sus rivales políticos, la hipérbole siempre será un recurso efectivo.

A principios de noviembre de ese año se celebró en Moscú el LX aniversario de la revolución de octubre, y con motivo de la misma se desplazó hasta allí una delegación del

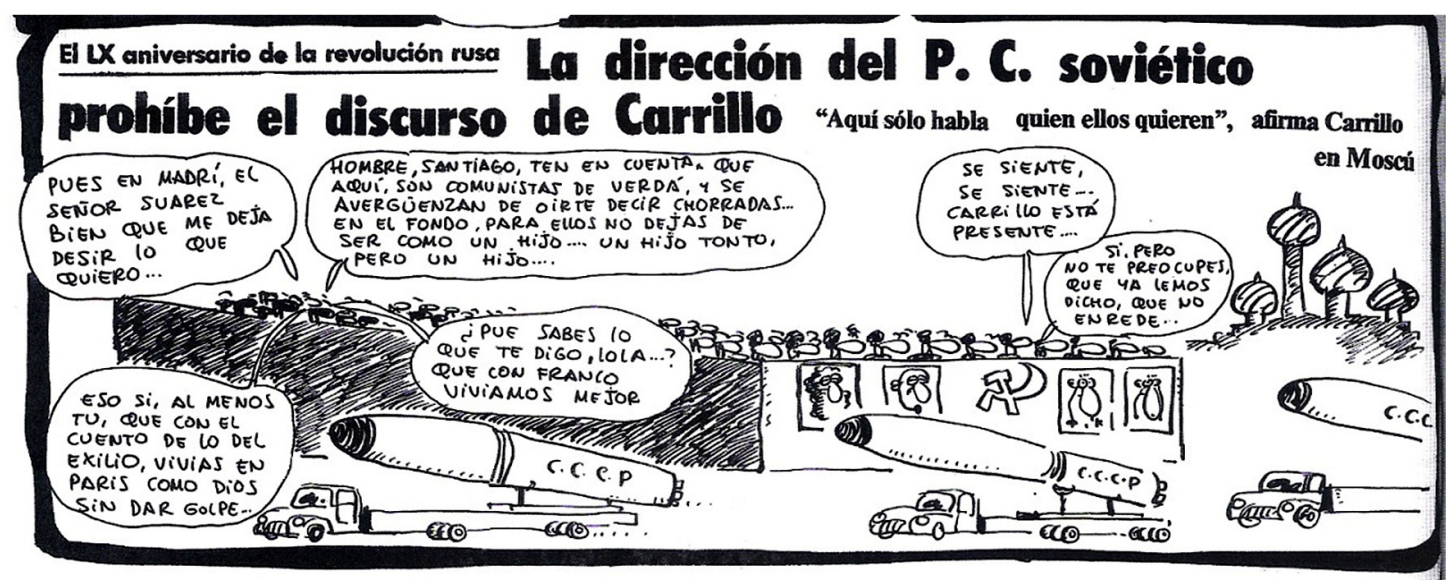

FIG. 7. IvÁ. "La historia sagrada contada a los niños". Detalle. En El Jueves n. ${ }^{\circ} 25$ (11 de noviembre de 1977), p. 6.

\footnotetext{
36 Ibid., p. 31.

37 Ibid.

38 Martín, J.L. “Historias de ciencia-ficción. Esta semana: '24 horas' - Diario íntimo de Santi Carrillo”. En El Jueves n. 8 (15 de julio de 1977), pp. 8-9.
} 
PCE encabezada por Santiago Carrillo, a quien finalmente, como informó El País, no se le permitió intervenir. ${ }^{39}$ No es extraño, dado que el partido y el propio Carrillo se habían manifestado ya contra la sumisión al aparato soviético. Ivá, en el primer número de la revista en el que colaboró, se burló de Carrillo insinuando que en el exilio, y con Franco, le iban mejor las cosas. ${ }^{40}$

Carrillo, de hecho, va a ser una de las víctimas favoritas de Ivá a partir de entonces. Ivá, al que podemos considerar el desencantado por excelencia de esta etapa de la revista, siempre se posicionó del lado de los trabajadores y los represaliados, y mostró por norma un radical escepticismo hacia todos los políticos, especialmente, al menos en estos momentos, hacia los de la izquierda. Cuando dos semanas después Carrillo anuncie la ruptura oficial con el leninismo para ser un partido únicamente marxista, Ivá dibujará una viñeta ${ }^{41}$ en la que alude a los hermanos Marx y escribe "No solo los de Alianza Popular van a tener gracia para estas cosas", en alusión a la moderación política de las fuerzas más ideológicamente extremas. En el número anterior es el eurocomunismo el objeto de escarnio, en dos chistes diferentes, en uno de los cuales aparece Carrillo intentando ser recibido por Tito, que se excusa a través del servicio por estar en el váter. ${ }^{42}$

\section{Comienza una nueva etapa: la compra por parte de Grupo Zeta.}

El número 26 de la revista es el último de esta primera etapa. A partir del n. ${ }^{\circ} 27$ el semanario pasa a ser editado por el Grupo Zeta. Antonio Asensio, el propietario, había llamado a Ilario para que volviera a Zeta, donde había desarrollado otros proyectos con anterioridad. Como sus socios de entonces, Jordi Pujol y la Banca Catalana, estaban liquidando otras cabeceras, Ilario llega a un acuerdo con ellos y se lleva a Grupo Zeta Editorial Formentera y Ediciones Primera Plana — bajo la cual editaba una revista del mismo nombre- Los cambios más inmediatos son estéticos: por primera vez la portada y contraportada son a todo color, en lugar del bitono. La maqueta mejora en algunos pequeños detalles que la hacen parecer más profesional, por ejemplo, en los pies de página, donde ahora puede leerse el anagrama de la revista junto al número de página. Lo más llamativo es que ahora aparece un encarte central de cuatro páginas a color y mejor papel. En la primera de esas páginas aparece "El Señor esté con nosotros" de José Luis Martín, y en las dos centrales, por primera vez, se encuentra una fotonovela, "Cara y culo de la noticia", de carácter humorístico pero también erótico, con desnudos parciales de mujeres. Es una imitación bastante descarada de "La Papunovela", una fotonovela de carácter erótico que El Papus llevaba publicando varios años, con algunas ausencias provocadas por el endurecimiento en la aplicación de la legislación. La última página a color del encarte se reservaba en este número a la publicidad, aunque en los inmediatamente posteriores se aprovecharán para dedicarle más páginas a la fotonovela. En esos números las portadas también van a ser fotografías de actores caracterizados, lo cual acerca aún más el estilo de la revista al de El Papus. De hecho, ya hemos mencionado a dos autores que se incorporan a El Jueves justo antes de la compra por parte del Grupo Zeta, Ós-

\footnotetext{
39 "Aquí sólo hablan quien ellos quieren" afirma Carrillo en Moscú. El País, 4 de noviembre de 1977. Disponible on line en http://elpais.com/diario/1977/11/04/internacional/247446022_850215.html

40 Ivá. "La historia sagrada contada para los niños". En El Jueves n. ${ }^{\circ} 25$ (11 de noviembre de 1977), p. 6.

${ }^{41}$ Ibid. En El Jueves n. 27 (25 de noviembre de 1977), p. 6.

${ }^{42}$ Ibid. En El Jueves n. 25 (11 de noviembre de 1977), p. 6.
} 


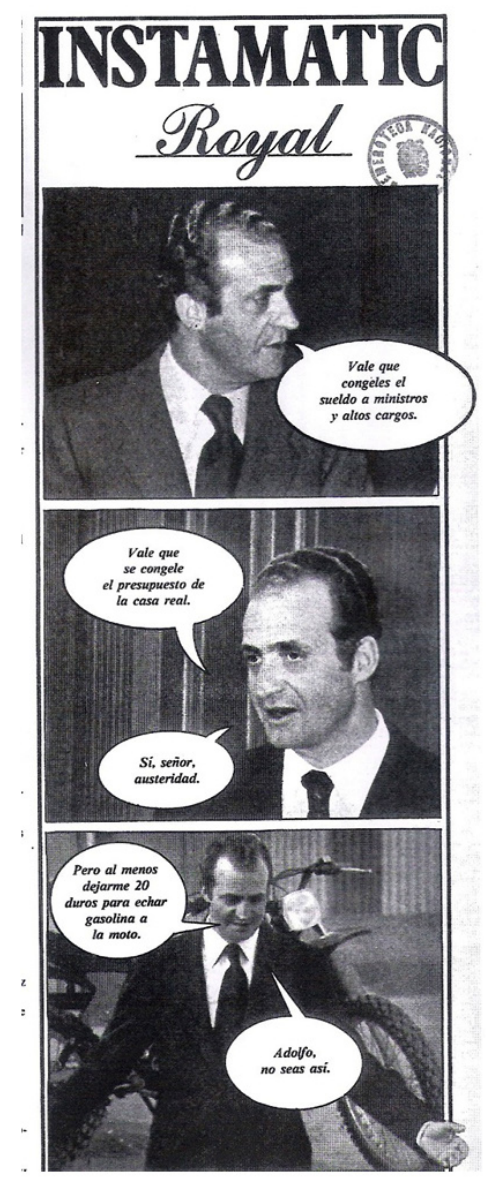

FIG. 8. Autor no acreditado. "Instamatic Royal". En El Jueves n. 27, p. 3.

car Nebreda e Ivá, ambos provenientes de El Papus, que acababa de sufrir el tremendo trauma de un atentado con bomba por parte de la ultraderecha que tuvo lugar el 20 de septiembre de 1977, y que a juicio de algún colaborador provocó que los dueños del semanario quisieran rebajar sus contenidos. ${ }^{43}$ Hay otra cuestión que mencionar: la primera parodia de Juan Carlos I. ${ }^{44}$

El resto de los contenidos no difieren demasiado de lo que venía desarrollándose después del giro político que he analizado en el anterior epígrafe. La revista prosigue con el recrudecimiento de sus críticas y el progresivo interés en los asuntos políticos, motivado por la propia agenda del país. Se ha convertido en unos pocos meses, en tan solo 26 números, en una herramienta imprescindible para constatar el desencanto que ya entonces embargaba a una parte de la ciudadanía española con respecto a los términos y maneras en las que se estaba construyendo la democracia española.

Confrontar las críticas amargas de estas revistas, tanto al sistema como a los partidos de izquierda que están cediendo en asuntos fundamentales en aras del consenso ${ }_{-} \mathrm{O}$,

\footnotetext{
${ }^{43}$ En estos términos se ha manifestado Carlos Giménez: "Después de la bomba quedó claro lo que era $E l$ Papus, se hacían aquellos chistes porque se vendían, pero si les iban a poner una bomba se hacían de otra cosa. Se vio mucha falsa ideología". En Trashorras, A. y Muñoz, D. "Entrevista con Carlos Giménez", en U, el hijo de Urich 9, (1998).

${ }^{44}$ Autor no acreditado. "Instamatic Royal". En El Jueves n. ${ }^{\circ}$ 27, p. 3.
} 
como interpretarán los semanarios, en aras de entrar en el juego del poder- con la versión institucional del proceso que acabó imponiéndose se revela así como un ejercicio esencial para articular la crítica que de la Cultura de la Transición se está haciendo en la actualidad. En los meses siguientes, según Fontes y Menéndez "se arrincona el feísmo" y "el mensaje político de su humor va adaptándose a las transformaciones de un país". ${ }^{45}$ Durante cinco años, El Jueves se beneficia de pertenecer a un emporio editorial como Grupo Zeta y de una mejor distribución. Pronto, de todas sus competidoras, solo quedará El Papus, moderado tras el atentado y sin varios de sus principales dibujantes, que se marcharon a El Jueves, como vimos. En 1982 algún alto cargo llega a la conclusión de que la revista no es rentable y hay que cerrarla, momento en el que varios de los dibujantes dan un paso al frente y deciden comprarla. Gin, Óscar Nebreda y José Luis Martín llegan a un trato con Asensio y la compran para editarla en El Jueves S. A. En 1992, la tirada de la revista alcanzaba los 200.000 ejemplares. ${ }^{46}$

\footnotetext{
${ }^{45}$ Fontes, I., Menéndez, M.A. Op. cit. p. 583.

${ }^{46}$ Ibid., p. 584.
} 


\section{Apéndice}

La siguiente tabla resume todas las series de historieta que aparecieron durante los primeros veintiséis números de la revista. He decidido obviar únicamente aquellas secciones que solo tuvieron una entrega. Los títulos aparecen en la tabla por estricto orden de aparición.

\begin{tabular}{|l|l|l|}
\hline SERIE & AUTOR & NÚMEROS \\
\hline Martínez el facha & Kim & 1 a 26 \\
\hline Leopoldo (un oficinista que es el colmo) & José Luis Martín & 1 a 5 \\
\hline Pepe Progre & Tom & 1 a 4 \\
\hline El padre Cirilo & Vives & 1 a $8 ; 10$ a 25 \\
\hline Don Tristan Vallejo y Riuet & Romeu & 1 a $5 ; 8$ a 10 \\
\hline Betty & Romeu & 1 a 20; 22 a 23 \\
\hline El funcionario neura / El funcionario loco & Don Ángel & 1 a 6 \\
\hline Rodolfo Valentín siempre va caliente & José Luis Martín & 1 a 5 \\
\hline El bar de Paco & Tom & 1 a 5 \\
\hline El cortijo del señorito & Trallero & 1 a 26 \\
\hline La gallina de la paz & Bosch & 3 a 9 \\
\hline Nitka & Nitka & 6 a $8 ; 10$ a $11 ; 13$ a 15; 19 a 20 \\
\hline Historias de ciencia-ficción & José Luis Martín & 6 a $10 ; 12 ; 15 ; 17$ \\
\hline La carrera de San Jerónimo & Dino & $7 ; 10$ a 26 \\
\hline La señora de Mariano Ultra & Vives & 9 a 17 \\
\hline Diario íntimo de... & José Luis Martín & $11 ; 13$ a $14 ; 19$ a 26 \\
\hline A la cama no te irás sin aprender algo más & Romeu & 11 a $12 ; 14$ \\
\hline Desinforme semanal & Tom & 19 a $20 ; 22$ a 26 \\
\hline Historias / Aerofagias & José Luis Martín & 19 a 24 \\
\hline Nuestras dobles versiones & D’A & $19 ; 21$ a 23 \\
\hline Nuevas aventuras de la “Liga de los sin bata" & Romeu & 20 a 23 \\
\hline Los hijos de su madre & Romeu & 24 a 26 \\
\hline La historia sagrada contada a los niños & Ivá & 25 a 26 \\
\hline El Señor esté con nosotros & José Luis Martín & 25 a 26 \\
\hline
\end{tabular}




\section{Fuentes consultadas}

El Jueves n. 1 a 27 (1977). Ediciones Formentera (excepto n. ${ }^{\circ} 27$, Grupo Zeta).

Por Favor n. ${ }^{\circ}$ 100, año IV (31 de mayo de 1975). Punch Ediciones.

\section{Bibliografía}

Cuesta, J. "Recuerdo, silencio, y amnistía en la transición y en la democracia españolas (19752006)", en Studia historica. Historia Contemporánea, n. 25 (2007), pp. 125-165.

Fontes, I., Menéndez, M. A. El parlamento de papel. Las revistas españolas en la transición democrática, vol. 1. Madrid, Asociación de la Prensa de Madrid, 2004.

García, S. "Supermachos", en Mandorla, 2 de diciembre de 2010, disponible on line en http:// santiagogarciablog.blogspot.com.es/2010/12/supermachos.html

Martínez, G. "El concepto CT", en CT o la Cultura de la Transición. Crítica a 35 años de cultura española. Madrid, DeBolsillo, 2012.

Pérez Del Solar, P. Imágenes del desencanto. Nueva historieta española. 1980-1986. Madrid, Iberoamericana / Vervuert, 2013.

SuÁrez, J. "Los Pactos de la Moncloa o el triunfo de la concordia", en Historia y vida n. ${ }^{\circ} 355$ (1997), pp. 29-34.

Trashorras, A. y Muñoz, D. “Entrevista con Carlos Giménez”, en U, el hijo de Urich 9, (1998).

Treglia, E. "Un partido en busca de identidad", en Historia del presente n. ${ }^{\circ} 18$ (2011/2), 2. ${ }^{\text {a }}$ época, pp. 25-41.

Tubau, I. El humor gráfico en la prensa del franquismo. Barcelona, Editorial Mitre, 1987. 